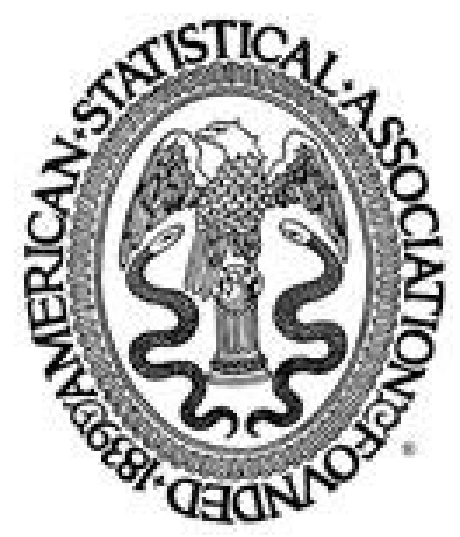

Testing for Choice Dynamics in Panel Data

Author(s): Tulin Erdem and Baohong Sun

Source: Journal of Business \& Economic Statistics, Vol. 19, No. 2 (Apr., 2001), pp. 142-152

Published by: American Statistical Association

Stable URL: http://www.jstor.org/stable/1392159

Accessed: $28 / 01 / 201014: 59$

Your use of the JSTOR archive indicates your acceptance of JSTOR's Terms and Conditions of Use, available at http://www.jstor.org/page/info/about/policies/terms.jsp. JSTOR's Terms and Conditions of Use provides, in part, that unless you have obtained prior permission, you may not download an entire issue of a journal or multiple copies of articles, and you may use content in the JSTOR archive only for your personal, non-commercial use.

Please contact the publisher regarding any further use of this work. Publisher contact information may be obtained at http://www.jstor.org/action/showPublisher?publisherCode=astata.

Each copy of any part of a JSTOR transmission must contain the same copyright notice that appears on the screen or printed page of such transmission.

JSTOR is a not-for-profit service that helps scholars, researchers, and students discover, use, and build upon a wide range of content in a trusted digital archive. We use information technology and tools to increase productivity and facilitate new forms of scholarship. For more information about JSTOR, please contact support@jstor.org.

American Statistical Association is collaborating with JSTOR to digitize, preserve and extend access to Journal of Business \& Economic Statistics. 


\title{
Testing for Choice Dynamics in Panel Data
}

\author{
Tülin ERDEM \\ Haas School of Business, University of California, Berkeley, CA 94720-1900 (erdem@haas.berkeley.edu)
Baohong SuN
Graduate School of Industrial Administration, Carnegie Mellon University, Pittsburgh, PA 15213-3890
(bsun@andrew.cmu.edu)

\begin{abstract}
This article applies different approaches to distinguish state dependence from unobserved heterogeneity and serial correlation and, hence, test for state dependence in consumer brand choices. First, we apply a simple method proposed by Chamberlain, which involves lagged exogenous variables only. Second, we also estimate a lagged-dependent-variable specification proposed by Wooldridge. Third, we use the estimation approach suggested by Wooldridge to estimate a model with both lagged dependent and exogenous variables to distinguish between the two different sources of choice dynamics, state dependence and lagged effects of the exogenous variables. Our analysis reveals that the best approach is to use models with both lagged dependent and exogenous variables. Our findings include strong evidence for state dependence in five out of the six product categories studied in this article.
\end{abstract}

KEY WORDS: Consumer choice; State dependence; Unobserved heterogeneity.

\section{INTRODUCTION}

Consumer choice behavior may exhibit dynamics for two distinct reasons. First, there may be state dependence in choice behavior; that is, choices made in previous periods may causally affect a consumer's current choices. Thus, as a consequence of experiencing an event, preferences or constraints relevant to future choices may be altered; therefore, individuals who have experienced an event in the past may be more likely to experience that event in the future. This type of temporal dependency in choice is referred to as "true" state dependence (Heckman 1981).

Second, there may be dynamic responses to exogenous variables. In marketing, the stream of literature on temporal dependencies in choice due to dynamic responses to exogenous variables focused primarily on reference price effects in brand choice (Winer 1986). Furthermore, advertising carryover effects (Tellis 1988; Pedrick and Zufryden 1991) have been analyzed as well, albeit to a lesser extent.

The stream of research that focused on state dependence, on the other hand, has intensively studied the order of the consumer brand-choice process, where a higher than zero-order Markov process indicates the existence of state dependence. Although Uncles, Ehrenberg, and Hammond (1995) indicated that applications of the Dirichlet model have provided strong evidence for zero-order choice processes, there still seems to be a great deal of disagreement on this issue. Indeed, recent work on state dependence and heterogeneity in the context of disaggregate panel data of consumer brand choices has brought the discussion about the order of the choice processes under new light.

In particular, marketing researchers have realized the importance of disentangling heterogeneity and state dependence in brand-choice models (see Keane 1997 for a review). The empirical observation that consumers tend to buy the same subset of brands repeatedly can be explained by either state dependence or unobserved heterogeneity; that is, individuals may differ in certain unmeasured variables that influence their probability of experiencing the event. This is called heterogeneity in unobserved variables (such as preferences, price sensitivities, etc.). If these unobserved variables are correlated over time and are not properly controlled, previous experience may appear to be a determinant of future experience solely because it is a proxy for such temporally persistent unobservables. Therefore, one needs to account for unobserved heterogeneity and other sources of serial correlation in unobservables to be able to make any inferences about true state dependence.

This article attempts to show that researchers may need to account for both state dependence and dynamic responses to exogenous variables to test for the effects of either. More specifically, this article aims to adopt relatively simple approaches to distinguish between the two main causes of choice dynamics-namely, state dependence and dynamic effects of exogenous variables-while controlling for unobserved heterogeneity.

A simple test was suggested by Chamberlain (1978) to distinguish state dependence from heterogeneity and serial correlation. Chamberlain noted that the key distinction between heterogeneity and state dependence is dynamic response to exogenous variables. Chamberlain's test consists of including lagged exogenous variables (but not lagged choices) in the utility specification while allowing for unobserved heterogeneity in the taste and response parameters (Hsiao 1986).

If true state dependence is present, lagged exogenous variables affect current choices because they affect lagged choices. But if true state dependence is not present, lagged exogenous variables cannot affect current choices. Thus, Chamberlain argued that a test for whether lagged exogenous variables are significant determinants of current choices would be a test for state dependence. Further, he argued that such a test would have important advantages over tests based on significance of lagged-dependent-variable models.

A key point is that estimates of lagged-dependent-variable models are only consistent if the functional form for serial correlation-that is, the serial-correlation structure-in the

(C) 2001 American Statistical Association Journal of Business \& Economic Statistics April 2001, Vol. 19, No. 2 
errors is correctly specified. If the serial-correlation structure is misspecified, the lagged-dependent-variables may be spuriously significant, simply because they help to fit the temporal dependency in the data better. As Heckman (1981) pointed out, one will get spurious state dependence if there are random effects but the econometrician falsely assumes that errors are serially independent. However, the point is more general. For instance, if the errors are $\operatorname{AR}(1)$ (first-order autoregressive) and the econometrician assumes random effects, it will also lead to inconsistent estimates of lagged-dependentvariable coefficients (as will any misspecification of the serialcorrelation structure).

The important virtue of Chamberlain's test is that it does not rely on a correct specification of the serial-correlation structure in the errors because the model he estimated to implement the test did not include lagged endogenous variables. As is well known, if the heterogeneity and/or serial-correlation structure is misspecified in models that do not contain lagged endogenous variables, it typically only causes inefficiency, not inconsistency of the estimates. Thus, Chamberlain argued that his proposed test should be reasonably robust to misspecification of the functional form for heterogeneity and/or serial correlation. Note that when Chamberlain argued about "insensitivity to functional form" he was not referring to the assumption of the distribution of the errors or the functional from of the relationship between the dependent variable and exogenous variables. Rather, this term needs to be interpreted as "insensitivity to serial-correlation structure."

We should note, however, that a random-effects implementation of the Chamberlain test cannot be said to be strictly robust to serial-correlation structure since there is no theoretical proof that the random-effects estimator is robust to arbitrary serial correlation in errors in the context of discretechoice models (which are nonlinear models). However, past empirical evidence on discrete-choice models (with random effects) has indicated that misspecification of serial-correlation structure has fairly minor effects on the estimates of the coefficients for exogenous variables. For example, Keane (1997) found that the estimates of coefficients for exogenous variables such as price obtained in brand-choice models with random effects and autoregressive errors were not very different from estimates obtained from random-effects-only models, despite the fact that the AR(1) coefficient was highly significant.

To give a concrete example of how Chamberlain's test works, suppose that the lagged covariate that is included in the model is price. Now further suppose that only current prices matter in current brand-choice decisions (e.g., there are no lagged price effects) but that state dependence exists due to habit persistence-that is, reinforcement of consumer tastes due to past consumption (Erdem 1996). Given that there is habit persistence, a consumer is more likely to buy a brand at the current purchase occasion if this consumer bought it on the previous occasion. Although lagged price has no effect on the current utility, a low lagged price means that the consumer is more likely to have bought the brand at the previous purchase occasion. Then, even though lagged price does not have any effect on the current purchase decision, the habit persistence induces a negative correlation between lagged price and the current purchase probability for a brand. Chamberlain's approach entails testing for such a correlation.
There are three drawbacks of the Chamberlain test. First, the test cannot be used to make further distinctions with regard to different forms of state dependence, heterogeneity, and serial correlation. Second, Chamberlain's test depends on the assumption of individual effects being uncorrelated with the covariates if a random-effects specification is used to implement the test (or else that any such correlation be correctly modeled). Third, Chamberlain's test as a "test of state dependence" requires at least one exogenous variable that would not have a lag structure in the absence of state dependence (Chamberlain 1978; Wooldridge 1998). If dynamic responses to any exogenous variable cannot be ruled out, Chamberlain's test becomes only a test of choice dynamics (i.e., temporal dependencies in the deterministic part of utility). This is because the test does not differentiate between state dependence and lagged responses to exogenous variables. For example, if price is the exogenous variable in the context of a multinomial logit or probit model estimated on household-level scanner panel data and if the lagged price coefficient is found to be statistically significant, we do not know whether choice dynamics occur due to true state dependence or dynamic price effects (e.g., reference price effects). In this specific example, we can only conclude that there are temporal dependencies in the deterministic part of utility and hence in choices; however, if the lagged effects are insignificant, then we can rule out state dependence.

However, important criticisms hold for the use of laggeddependent-variable models to account and test for state dependence as well. First, as argued in the literature, the test for state dependence involving a lagged-dependent-variable model may be sensitive to the specification of unobserved heterogeneity and serial correlation, as well as the functional form of state dependence (Keane 1997). However, even more importantly, the existence of significant dynamic responses to exogenous variables may be problematic for tests of state dependence involving models with only lagged dependent variables and no lagged exogenous variables. More specifically, if there are true dynamic responses to exogenous variables that are omitted from the model, the lagged dependent variable may be spuriously significant simply because it is correlated with the omitted lagged exogenous variables. This issue has never been acknowledged before in the marketing literature.

This article's objectives are twofold. The first objective is to describe in more detail the test developed by Chamberlain and apply it in the context of brand-choice models on scanner panel data. In this context, we also investigate whether Chamberlain's test serves as a valid test for state dependence in the product categories we analyze. More specifically, we test both whether true dynamic responses to exogenous variables under analysis exist and whether individual effects are independent of the covariates in the categories we analyze. The second objective is to explore and discuss the relative merits of different approaches to test for state dependence. We accomplish these objectives by estimating lagged-exogenousvariable models, as well as lagged-dependent-variable models with and without lagged exogenous variables.

We find evidence for choice dynamics in five categoriesnamely, ketchup, peanut butter, detergent, tissue, and tuna. We could not reject the null hypothesis of no choice dynamics in 
sugar. Furthermore, the results indicate that true state dependence is present in all five categories where choice dynamics are found. We do not find any significant simple lagged price and display effects in these categories. Hence, Chamberlain's test seems to function as a test of state dependence in the categories analyzed. Finally, for the first time in the marketing literature, we test whether individual effects are uncorrelated with the covariates. We find individual effects to be uncorrelated with the covariates in all six categories we studied. Most importantly, we show that a combination of tests needs to be used to avoid the shortcomings of each test as a stand-alone test of state dependence.

The rest of the article is organized as follows. In the next section, we briefly review the literature on brand-choice dynamics. After that, we introduce the models we estimate to test for choice dynamics and discuss their implications for research on choice models. Then we present the empirical results. The last section makes brief concluding remarks.

\section{LITERATURE REVIEW}

Since the seminal article by Guadagni and Little (1983), several researchers have included a Guadagni and Little type of brand-loyalty variable-that is, a lagged-past-purchases variable-in the specification of the utility function when modeling individual-level brand choice. Many of these studies, including that of Guadagni and Little, found state dependence (as operationalized by a brand-loyalty variable) to be statistically significant (e.g., Gupta 1988; Tellis 1988; Pedrick and Zufryden 1991; Ailawadi, Gedenk, and Neslin 1999).

A related stream of research analyzed the order of the choice process within the context of Markov models. The evidence obtained from these studies is mixed. Givon (1984) found weak evidence for a specific form of state dependencenamely, variety-seeking behavior. Bass et al. (1984) reported that around $70 \%$ of the families studied showed zero-order choice behavior. Kahn, Kalwani, and Morrison (1986), on the other hand, found significant state dependence for most brands they analyzed.

However, when researchers realized that not accounting for unobserved heterogeneity may lead to spurious state dependence (Heckman 1981), this accumulated "evidence" on state dependence was called into question. Indeed, Bass and Wind (1995) indicated zero-order consumer brand-choice behavior to be an empirical generalization. However, over the past few years, several studies incorporated both state dependence and unobserved heterogeneity in the context of choice models (e.g., Gönül and Srinivasan 1993; Roy, Chintagunta, and Haldar 1996; Keane 1997) and found some evidence for state dependence. Given this mixed evidence, there still seems to be controversy about the existence of state dependence in choice in the context of frequently purchased product categories.

\section{A SIMPLE TEST FOR CHOICE DYNAMICS}

\subsection{Chamberlain's Test}

To analyze the intertemporal relationships among discrete variables, Heckman (1981) proposed a general framework.
A special case of his framework is given in (1), where the continuous random variable $y^{*}$ is a function of exogenous variables and past occurrence of the event:

$$
y_{i t}^{*}=\beta^{\prime} x_{i t}+\gamma y_{i, t-1}+\nu_{i t}
$$

Note that $y_{i t}$ is 1 if $y_{i t}^{*}>0$ and it is 0 if $y_{i t}^{*} \leq 0$, where $i$ denotes the observation and $t$ the time period. The coefficient $\gamma$ measures the effect of experience of the event one period ago on current values of $y_{i t}^{*}$. The error term $\nu_{i t}$ is assumed to be independent of $x$ and is independently and randomly distributed over $i$.

However, such lagged-dependent-variable specifications as tests of state dependence may be sensitive to various assumptions about unobserved heterogeneity and serial correlation. Hence, Chamberlain (1978) suggested a simple method to distinguish true state dependence from spurious state dependence. He noted that, just as with the continuous models, a key distinction between state dependence and serial correlation is whether or not there is a dynamic response to an intervention. If $\gamma=0$, a change in $x$ has its full effect immediately, whereas if $\gamma$ is not equal to 0 , this implies a lagged response to a change in $x$. The lag structure relating $y$ to $x$ is not related to the serial correlation in $\nu$. If $x$ is increased in period $t$ and then returned to its former level, the probability of $y_{i, t+1}$ is not affected if $\gamma$ is equal to 0 because by assumption the distribution of $\nu_{i t}$ was not affected. If $\gamma_{1} \neq 0$, then the one-period shift in $x$ will have an effect in the next period (or lasting effects if the distributed lag structure involves all past events). Thus, an intervention that affects the probability of $y$ in period $t$ will continue to affect the probability of $y$ in period $t+1$.

Thus, a test that should not be very sensitive to the specification of serial correlation and heterogeneity structure would simply include lagged $x$ 's without lagged $y$ (Chamberlain 1978 , p. 23). After conditioning on the individual-specific effects $\alpha_{i}$ (i.e., after controlling for unobserved heterogeneity), there may be two outcomes. In a choice situation with two alternatives, if there is no choice dynamics, then

$$
\operatorname{Pr}\left(y_{i t}=1 \mid x_{i t}, x_{i, t-1}, \ldots, \alpha_{i}\right)=\operatorname{Pr}\left(y_{i t}=1 \mid x_{i t}, \alpha_{i}\right),
$$

and if there are choice dynamics, then

$$
\operatorname{Pr}\left(y_{i t}=1 \mid x_{i t}, x_{i, t-1}, \ldots, \alpha_{i}\right) \neq \operatorname{Pr}\left(y_{i t}=1 \mid x_{i t}, \alpha_{i}\right) \text {. }
$$

However, as we discussed in the previous section, if indeed Chamberlain's test shows significant coefficients for lagged variables, the analyst would not know whether this is due to state dependence or significant dynamic effects of exogenous variables or both. Thus, for Chamberlain's test to be a valid test of state dependence it is necessary that there be at least one exogenous variable whose lagged values would not affect current choices in the absence of state dependence. If such a variable exists, and if we find the coefficient of the lagged term in Chamberlain's test to be significant, then we can conclude that state dependence exists. Similarly, if the coefficients for the lagged terms are insignificant, then we fail to reject the null hypotheses of no state dependence.

Note that Chamberlain's test should not be sensitive to the specification of unobserved heterogeneity and, in general, the 
specification of the serial correlation structure simply because Chamberlain's test does not involve a lagged dependent variable. More specifically, since there is no lagged dependent variable in the model, the problem of the upward bias in the lagged-dependent-variable coefficient due to uncaptured unobserved heterogeneity or serial correlation does not arise. For example, Keane (1997) showed that adding more complex heterogeneity structures decreased the magnitude and significance of the state-dependence coefficient. However, even after allowing for very complex heterogeneity structures, he still found evidence for statistically significant, albeit small in magnitude, state-dependence effects.

Finally, it should be noted that Chamberlain's test requires that the individual effects $\left(\alpha_{i}\right)$ be uncorrelated with the $x$ 's if a random-effects model is used to implement the test. However, if the individual effects are indeed correlated with the $x$ 's, then one needs to use a fixed-effects specification. Nonetheless, in the context of multinomial choice (as is the case with brand choice), it is infeasible to estimate discrete choice models with fixed effects. Hence, in the context of brand choice, one needs to use a random-effects model to implement the Chamberlain test. We should also note that a random-effects specification is very plausible in this context since empirically it is implausible for the covariates such as lagged price or lagged display to be correlated with individual effects-that is, brand preferences. However, we will be testing this assumption in our empirical analysis.

A very important point to note also is that the previously described implementation of the test is not robust with respect to the specification of serial-correlation structure. This is so because, in the random-effects case, the random-effects estimator is not proven to be robust to arbitrary serial correlation in the errors. However, as we previously discussed in Section 1, empirical evidence (e.g., Keane 1997) suggests that the parameter estimates obtained from models with random effects and autoregressive errors versus estimates obtained from random-effects models only are very similar. Additionally, this insensitivity to the structure of serial correlation in errors is only found when lagged dependent variables are not included in the model (Keane 1997). Since Chamberlain's test involves only lagged exogenous variables and no lagged endogenous variables, the random-effects implementation of the test is likely to be quite robust to serial-correlation structure as well.

An alternative test for state dependence would involve a simple lagged-dependent-variable model. To describe his approach, let us specify the following general structure for a problem with two alternatives (Wooldridge 1998):

$$
\begin{aligned}
P\left(y_{i t}\right. & \left.=1 \mid y_{i, t-1}, \ldots, y_{i 0}, \mathbf{x}_{i}, \alpha_{i}\right) \\
& =G\left(\mathbf{x}_{i t} \beta+\rho_{1} y_{i, t-1}+\alpha_{i}\right)
\end{aligned}
$$

where $\mathbf{x}_{i t}$ is a vector of explanatory contemporaneous variables, $\mathbf{x}_{i}=\left(\mathbf{x}_{i 0}, \mathbf{x}_{i 1}, \ldots, \mathbf{x}_{i T}\right)$, and $\mathrm{G}$ can be a logit or probit function. The test for state dependence is $H_{o}: \rho_{1}=0$, after controlling for unobserved heterogeneity, $\alpha_{i}$.
We can write the density associated with (4) as the following:

$$
\begin{array}{r}
f\left(y_{1}, y_{2}, \ldots, y_{T} \mid y_{0}, \mathbf{x}, \alpha ; \boldsymbol{\beta}\right)=\prod_{t=1}^{T} G\left(\mathbf{x}_{t} \boldsymbol{\beta}+\rho_{1} y_{t-1}+\alpha\right)^{y_{t}} \\
\cdot\left[1-G\left(\mathbf{x}_{t} \boldsymbol{\beta}+\rho_{1} y_{t-1}+\alpha\right)\right]^{1-y_{t}} .
\end{array}
$$

The estimation of (5) poses the challenge of the appropriate treatment of the initial observation, $y_{0}$. If $y_{0}$ is exogenous and fixed, one can treat it as an exogenous nonrandom initial condition, but this is problematic since independence of $y_{0}$ and $\left(x_{i}, \alpha_{i}\right)$ is a strong assumption. If $y_{0}$ is random, then we have the form $f\left(y_{0}, y_{1}, \ldots, y_{T} \mid \mathbf{x}, \alpha\right)=f\left(y_{1}, \ldots, y_{T} \mid\right.$ $\left.y_{0}, \mathbf{x}, \alpha\right) f\left(y_{0} \mid \mathbf{x}, \alpha\right)$. Then, to implement maximum likelihood (ML), we have to specify $f\left(y_{0} \mid \mathbf{x}, \alpha\right)$. Unfortunately, $f\left(y_{0} \mid \mathbf{x}, \alpha\right)$ can be intractably complex, and its construction requires modeling the process from its start up to first observation $t=0$.

Recently, Wooldridge (1998) suggested a third approach: Form the joint distribution of $\left(y_{i 1}, y_{i 2}, \ldots, y_{i T}\right)$ given $\left(y_{i 0}, \mathbf{x}_{i}\right)$ and use conditional ML. To obtain $f\left(y_{1}, y_{2}, \ldots, y_{T} \mid y_{i 0}, \mathbf{x}_{i}\right)$, one needs to postulate a density for $\alpha_{i}$ given $\left(y_{i 0}, \mathbf{x}_{i}\right)$, and then integrate out $\alpha_{i}$ of the joint density $f\left(y_{1}, y_{2}, \ldots, y_{T}\right.$ $\left.y_{i 0}, \mathbf{x}_{\mathbf{i}}, \alpha_{i}\right)$. A natural choice for a density $f\left(\alpha \mid \mathbf{x}, y_{0} ; \kappa\right)$ is a normal specification, depending on a vector of parameters $\kappa$ :

$\alpha_{i}=\alpha+a_{i}+\lambda y_{i 0}+\mathbf{x}_{i} \chi$,

where $a_{i} \sim \mathrm{N}\left(0, \sigma_{a}^{2}\right)$ and independent of $\left(y_{i 0}, \mathbf{x}_{i}\right)$.

Thus, if $\lambda$ and $\chi$ are found to be insignificant, this would suggest a random-effects model where $\alpha_{i}$ is uncorrelated with $y_{i 0}$ and $\mathbf{x}_{i}$.

The main trade-offs between Chamberlain's approach and approaches that involve estimation of lagged-dependentvariable models are the following. Chamberlain's test should not be sensitive to the specification of unobserved heterogeneity and serial correlation because it does not involve a laggeddependent-variable. However, it requires a lack of significant direct effects of at least one exogenous variable, and it requires a lack of correlation between the covariates and individual effects. Lagged-dependent-variable approaches, on the other hand, require the correct specification of any serial-correlation pattern. Furthermore, one may expect that, if there are significant direct effects of lagged exogenous variables and these are not captured in the model, then the lagged-dependent-variable coefficient may be found significant even if it there is no true state dependence.

Therefore, to circumvent the drawbacks of each approach, it is useful to apply a combination of tests to test for both state dependence and dynamic responses to exogenous variables under analysis.

\subsection{Testing for Choice Dynamics in Scanner Panels}

3.2.1 Chamberlain's Test: The Specification of the Utility Function. The tests described in Equations (2) and (3), which is the Chamberlain test, and in Equations (4), (5), and (6), 
which is the Wooldridge test, involved two alternatives. In this section, we will specify the index functions such that there are multiple alternatives. We will assume the index function $(G)$ to be a logit, and hence we will estimate multinomial logit models (McFadden 1974).

The test described in (2) and (3) involves exogenous variables only. This is indeed one of the reasons that underlie its simplicity. In the context of brand-choice models estimated on scanner panel data, the exogenous variable that explains most of the variance is price. Hence, we include price as an exogenous variable to test whether lagged price effects have any impact on choice.

Since there may be dynamic responses to prices (reference price effects) and Chamberlain's test requires at least one exogenous variable without any direct lagged effects, we also use display and lagged display as additional exogenous variables. In the case of the displays, there is no plausible theory of dynamic responses. Thus, we do not expect significant lagged display effects unless there is true state dependence. We will also estimate lagged-dependent-variable models with lagged prices and displays. Thus, we will be able to show whether lagged values of prices and displays affect current choices after controlling for the effects of the lagged dependent variable. Note also that, in the context of brand-choice models, there are a few exogenous variables, such as display and feature, for which there is no plausible economic theory or consumer behavior explanation of any direct lagged exogenous responses. Thus, the requirement of the Chamberlain test for at least one exogenous variable to have no significant dynamic responses in the absence of state dependence is easy to fulfil. Finally, we should also note that we assume prices and displays to be exogenous, which is the standard assumption in discrete-choice models estimated on individual (household)-level scanner panel data.

Another issue to be addressed is the number of lags to include in the analysis. To simplify the analysis, we include only the prices and display at the previous purchase occasion, since in the context of scanner panel data it is highly unlikely that the first lag is statistically insignificant although higherorder lags are statistically significant. Note that if we find the coefficient for the lagged price (or lagged display) to be statistically significant, this would indicate state dependence (under the assumption of insignificant true lagged price and display effects). Then, there is no need to check for further lags. When we did the empirical analysis, in the categories where the lagged terms turned out to be statistically insignificant, we included further lags such as Price $_{i j t-2}$ and Price $_{i j t-3}$. However, the coefficients for these variables were statistically insignificant as well. Hence, the one-lag structure seems to be adequate to test for state dependence in the datasets we used.

Thus, for the Chamberlain test, we specify the latent index of household $i$ for brand $j$ at purchase occasion $t,\left(y_{i j t}^{*}\right)$, to be

$$
\begin{aligned}
y_{i j t}^{*}= & \left(\alpha_{j}+a_{i j}\right)+\left(\beta+b_{i}\right) \text { Price }_{i j t} \\
& +\left(\beta+b_{L i}\right) \text { Price }_{i j, t-1}+\left(\omega+w_{i}\right) \text { Display }_{i j t} \\
& +\left(\omega+w_{L i}\right) \text { Display }_{i j, t-1}+\varepsilon_{i j t}
\end{aligned}
$$

where $\alpha_{i j}=\alpha_{j}+a_{i j}$ is the household and brand-specific constant, $\beta_{i}=\beta+b_{i}$ and $\beta_{L i}=\beta_{L}+b_{L i}$ are the price coefficients for the current and lagged prices, respectively, and $\omega_{i}=\omega+w_{i}$ and $\omega_{L i}=\omega_{L}+w_{L i}$ are the display coefficients for the current and lagged displays, respectively. We call the model based on Equation (7) Model 1.

We assume that $a_{i j}, b_{i}, b_{L i}, w_{i}$, and $w_{L i}$ are normally distributed with means 0 and variances $\sigma_{a}^{2}, \sigma_{b}^{2}, \sigma_{b_{L}}^{2}, \sigma_{w}^{2}$, and $\sigma_{w_{L}}^{2}$, respectively. Finally, we assume that the error terms $\varepsilon_{i j t}$, which are deterministic from the point of view of the household but are unobservable by the analyst, are iid. Thus, we assume that all serial correlation in unobservables is captured by the unobserved heterogeneity terms (as suggested by Chamberlain, the tests should not be sensitive to this assumption). Note that both the intercept term and the slope coefficients are allowed to be heterogeneous.

3.2.2 Wooldridge's Lagged-Dependent-Variable Model: The Utility Specification. In accordance with (4) and (5), we define the latent index for household $i$, brand $j$, and at purchase occasion $t$ to be

$$
\begin{aligned}
y_{i j t}^{*}=\alpha_{i j}+( & \left.+b_{i}\right) \text { Price }_{i j t} \\
& +\left(\omega+w_{i}\right) \text { Display }_{i j t}+\left(\rho+r_{i}\right) y_{i j, t-1}+\varepsilon_{i j t} .
\end{aligned}
$$

The individual-specific effects, $\alpha_{i j}$, are assumed to be normal, conditional on $\left(y_{i 0}, \mathbf{x}_{i}\right)$, with a linear mean, $\alpha_{i}$,

$$
\begin{aligned}
\alpha_{i j}=\alpha_{j}+ & a_{i j}+\left(\lambda+l_{i}\right) y_{i j 0} \\
& +\sum_{t=0}^{T} \operatorname{Price}_{i j t}\left(\eta+e_{i}\right)+\sum_{t=0}^{T} \operatorname{Display}_{i j t}\left(\pi+p_{i}\right),
\end{aligned}
$$

$y_{i j, t-1}=1$ if brand $j$ was purchased at purchase occasion $t-1$, and $y_{i j, t-1}=0$ otherwise. The coefficient for $y_{i j, t-1}$ is $\left(\rho+r_{i}\right) \cdot y_{i j 0}=1$ if brand $j$ was bought on the first purchase occasion (i.e., at $t=0)$, and it is 0 otherwise, $\left(\lambda+l_{i}\right)$ is the coefficient for $y_{i j 0}$, and $\sum_{t=0}^{T}$ Price $_{i j t}$ and $\sum_{t=0}^{T}$ Display $_{i j t}$ represent the price and display dummies for brand $j$ and household $i$ over the entire purchase history of a household (from $t=0$ to $T$, where $T$ denotes the last purchase occasion observed for that household in the calibration sample); $\left(\eta+e_{i}\right)$ and $\left(\pi+p_{i}\right)$ are their respective coefficients. Thus, all past prices and displays are constrained to have the same coefficients. Note also that the "price history" and "display history" variables, $\sum_{t=0}^{T}$ Price $_{i j t}$ and $\sum_{t=0}^{T}$ Display $_{i j t}$, are household specific since these vectors include prices and displays at the purchase occasions of that specific household. We call the model based on Equations (8) and (9) Model 2. We assume that $a_{i j}, b_{i}, w_{i}, r_{i} l_{i}, e_{i}$, and $p_{i}$ are normally distributed with means 0 and variances $\sigma_{a}^{2}, \sigma_{b}^{2}, \sigma_{w}^{2}, \sigma_{r}^{2} \sigma_{l}^{2}, \sigma_{e}^{2}$, and $\sigma_{p}^{2}$, respectively.

We should note that making the household brand-specific coefficient (brand preferences) a function of past price and display enables the researcher also to test for the viability of a random-effects specification where individual effects are uncorrelated with the covariates (recall that Chamberlain's test is based on this assumption if a random-effects specification is used to implement the test). 
Finally, we use the estimation approach suggested by Wooldridge (1998) to estimate a model with both lagged dependent and exogenous variables. We let the latent index function be

$$
\begin{aligned}
y_{i j t}^{*}= & \alpha_{i j}+\left(\beta+b_{i}\right) \text { Price }_{i j t}+\left(\beta+b_{L i}\right) \text { Price }_{i j, t-1} \\
& +\left(\omega+w_{i}\right) \text { Display }_{i j t}+\left(\omega+w_{L i}\right) \text { Display }_{i j, t-1} \\
& +\left(\rho+r_{i}\right) y_{i j, t-1}+\varepsilon_{i j t},
\end{aligned}
$$

where the household- and brand-specific coefficient is as defined in (9).

The specification in (10) allows us to distinguish between the two different sources of choice dynamics, state dependence and lagged effects of the exogenous variables (i.e., marketing mix effects). We call this Model 3. Finally, since Model 3 may suffer under multicollinearity problems because $\sum_{t=0}^{T}$ Price $_{i j t}$ and $\sum_{t=0}^{T}$ Display $_{i j t}$ in Equation (9) can correlate with Price ${ }_{i j, t-1}$ and Display ${ }_{i j, t-1}$ in Equation (10), we also estimate a model (Model 4) where we set $\left(\eta+e_{i}\right)$ and $\left(\pi+p_{i}\right)$ in Equation (9) to 0 to further test for dynamic responses to exogenous variables.

As discussed previously, if we do not find any significant lagged effects associated with the exogenous variables in Chamberlain's test (Model 1), we can rule out both state dependence and lagged effects of the exogenous variables under analysis. However, if we do find significant lagged effects, we would not know whether there is indeed state dependence or significant lagged effects of the exogenous variables. Nonetheless, if we find a significant lagged purchase effect in Model 2 (Wooldridge specification), that will be consistent with state dependence provided that any potential serial-correlation pattern is sufficiently captured. For example, we have allowed for random effects, but there may still be uncaptured serial correlation in the errors that follow some autoregressive process. Furthermore, if there are large and significant dynamic responses to exogenous variables (not modeled in Model 2), the state-dependence coefficient may be simply picking up such effects. Therefore, we need Model 3, which nests both the Chamberlain approach and Wooldridge's approach, to see whether the effects of lagged exogenous variables persist after accounting for the effect of the lagged dependent variable and to test for state dependence. Note also that the Model 2 and Model 3 results will shed light on whether the individual effects are uncorrelated with the covariates $(x$ 's)

To reiterate, the estimation of Model 1 (Chamberlain test) and the estimation of lagged-dependent-variable models (Models 2, 3, and 4) enable us to test for both state dependence and dynamic responses to exogenous variables under analysis and disentangle the two. This is so because to conclude for state dependence we need two results, (1) a result from Model 1 showing a significant coefficient for at least one lagged exogenous variable and (2) a result from a lagged-dependentvariable model with lagged exogenous variables (Model 3) showing an insignificant coefficient for the lagged exogenous variable that was found significant in Chamberlain's test (Model 1).

\subsection{Choice Probabilities and the Likelihood Function}

Let $\theta$ denote the vector of model parameters. $\theta$ consists of $\left(\alpha_{j}, \beta, \beta_{L}, \omega, \omega_{L}, \sigma_{a}^{2}, \sigma_{b}^{2}, \sigma_{b_{L}}^{2}, \sigma_{w}^{2}\right.$ and $\left.\sigma_{w_{L}}^{2}\right)$ in Model 1 given in Equation (7) (i.e., the Chamberlain test specification), $\left(\alpha_{j}, \beta, \omega, \rho, \lambda, \eta, \pi, \sigma_{a}^{2}, \sigma_{b}^{2}, \sigma_{w}^{2}, \sigma_{l}^{2}, \sigma_{e}^{2}\right.$, and $\left.\sigma_{p}^{2}\right)$ in Model 2 given in Equations (8) and (9) (the specification suggested by Wooldridge), and finally $\left(\alpha_{j}, \beta, \beta_{L}, \omega, \omega_{L}, \rho, \lambda, \eta, \pi, \sigma_{a}^{2}, \sigma_{b}^{2}, \sigma_{b_{L}}^{2}, \sigma_{w}^{2}, \sigma_{w_{L}}^{2}, \sigma_{l}^{2}, \sigma_{e}^{2}\right.$ and $\left.\sigma_{p}^{2}\right)$ in the general model specified in Equations (9) and (10) (Model 3). Model 4 will have the same parameter vector except for $\eta=\pi=\sigma_{e}^{2}=\sigma_{p}^{2}=0$. Let $\phi_{i}$ also denote the vector of all the household-specific random effects. $\phi_{i}$ will consist of $\left(a_{i}, b_{i}, b_{L i}, w_{i}, w_{L i}\right)$ in Model $1\left(a_{i}, b_{i}, w_{i}, l_{i}, e_{i}, p_{i}\right)$ in Model 2, $\left(a_{i}, b_{i}, b_{L i}, w_{i}, l_{i}, e_{i}, p_{i}\right)$ in Model 3, and $\left(a_{i}, b_{i}\right.$, $\left.b_{L i}, w_{i}, w_{L i}, l_{i}\right)$ in Model 4.

Further, assume that $\varepsilon_{i j t}$ in Equations (7), (8), and (10) are extreme value distributed. Then, rewriting all the models in the form, $y_{i j t}^{*}=V_{i j t}+\varepsilon_{i j t}$, we obtain McFadden's conditional logit formula (1974) for choice probabilities:

$$
\operatorname{Pr}_{i j t}\left(\theta, \phi_{i}\right)=\frac{\exp \left\{V_{i j t}\left(\theta, \phi_{i}\right)\right\}}{\sum_{k=1}^{J} \exp \left\{V_{i k t}\left(\theta, \phi_{i}\right)\right\}}
$$

Then, the probability of household $i$ making the sequence of purchases denoted by $d_{i j t}, j=1, \ldots, J$ and $t=1, \ldots, T$, conditional on $\theta$ and $\phi_{i}$, is

$$
\operatorname{Pr}_{i j t}\left(\theta, \phi_{i}\right)=\prod_{t=1}^{T} \prod_{j=1}^{J} \operatorname{Pr}_{i j t}\left(\theta, \phi_{i}\right)^{d_{i j}} .
$$

Integrating over $\phi_{i}$, we obtain

$$
\operatorname{Pr}_{i}(\theta)=\int_{\phi_{i}} \operatorname{Pr}_{i}\left(\theta, \phi_{i}\right) f\left(\phi_{i} \mid \theta_{s}\right) d \phi_{i},
$$

where $f\left(\phi_{i} \mid \theta_{s}\right)$ is the multinomial probability distribution function for $\phi_{i}$, conditional on $\theta_{S}$, and $\theta_{S}$ denotes the subset of the parameter vector that includes $\sigma_{\alpha}^{2}, \sigma_{\beta}^{2}, \sigma_{\beta_{L}}^{2}, \sigma_{\omega}^{2}$, and $\sigma_{\omega_{L}}^{2}$.

Given (13), the log-likelihood function to be maximized is

$$
\log L(\theta)=\sum_{i=1}^{N} \ln \left[\operatorname{Pr}_{i}(\theta)\right]
$$

where $N$ is the number of households. Note that, given the integration in (13), this function requires the evaluation of multiple integrals. We use simulated ML techniques to evaluate these multiple integrals. In the simulation estimation approach, one uses Monte Carlo methods to simulate the highorder integrals that enter the likelihood function rather than evaluating them numerically (Pakes 1987; McFadden 1989; Keane 1993, 1994).

\section{EMPIRICAL ANALYSIS}

\subsection{Data}

We test for choice dynamics in six frequently purchased packaged consumer product categories-ketchup, peanut butter, liquid detergent, tissue, tuna, and sugar. The data used are household-level scanner panel datasets collected from 
Table 1. Descriptive Statistics

\begin{tabular}{|c|c|c|c|c|}
\hline Category & Brand name & $\begin{array}{c}\text { Market } \\
\text { share (\%) }\end{array}$ & $\begin{array}{c}\text { Mean } \\
\text { price (\%) }\end{array}$ & $\begin{array}{c}\text { Display } \\
\text { (\%) }\end{array}$ \\
\hline Ketchup & $\begin{array}{l}\text { Heinz } \\
\text { Hunts } \\
\text { Store brands* }\end{array}$ & $\begin{array}{l}55.9 \\
12.5 \\
20.5(88.9)\end{array}$ & $\begin{array}{r}1.377 \\
.838 \\
1.186\end{array}$ & $\begin{array}{l}5.5 \\
4.5 \\
2.1\end{array}$ \\
\hline Peanut butter & $\begin{array}{l}\text { Skippy } \\
\text { Jif } \\
\text { CTL } \\
\text { Peter Pan* }\end{array}$ & $\begin{array}{l}40.5 \\
22.3 \\
17.7 \\
12.5(93.0)\end{array}$ & $\begin{array}{l}1.613 \\
1.658 \\
1.488 \\
1.602\end{array}$ & $\begin{array}{l}5.0 \\
4.8 \\
5.8 \\
2.3\end{array}$ \\
\hline Detergent (liq.) & $\begin{array}{l}\text { Wisk } \\
\text { Tide } \\
\text { Surf } \\
\text { Era } \\
\text { Solo } \\
\text { Cheer* }\end{array}$ & $\begin{array}{l}20.1 \\
18.2 \\
11.4 \\
8.3 \\
6.0 \\
5.8(69.8)\end{array}$ & $\begin{array}{l}2.946 \\
3.607 \\
3.153 \\
3.828 \\
3.725 \\
3.260\end{array}$ & \begin{tabular}{r|}
11.8 \\
10.4 \\
5.3 \\
4.2 \\
3.1 \\
1.6
\end{tabular} \\
\hline Tissue & $\begin{array}{l}\text { NRTHRM } \\
\text { CHRMN } \\
\text { CTNL } \\
\text { SCOTT } \\
\text { SF* }\end{array}$ & $\begin{array}{l}32.7 \\
31.4 \\
17.6 \\
7.6 \\
5.8(95.1)\end{array}$ & $\begin{array}{r}1.039 \\
1.044 \\
.946 \\
.970 \\
1.044\end{array}$ & $\begin{array}{r}.9 \\
.8 \\
1.4 \\
1.9 \\
2.1\end{array}$ \\
\hline Tuna (lite) & $\begin{array}{l}\text { Starkist } \\
\text { CKN of Sea* }\end{array}$ & $\begin{array}{l}47.6 \\
38.8(86.4)\end{array}$ & $\begin{array}{l}.684 \\
.622\end{array}$ & $\begin{array}{l}10.2 \\
12.5\end{array}$ \\
\hline Sugar & $\begin{array}{l}\text { CTL } \\
\text { EQUAL } \\
\text { American* } \\
\text { Generic*}^{*}\end{array}$ & $\begin{array}{r}42.48 \\
24.54 \\
10.30 \\
7.81(85.13)\end{array}$ & $\begin{array}{l}1.590 \\
1.263 \\
1.233 \\
1.167\end{array}$ & $\begin{array}{l}.5 \\
.4 \\
.4 \\
.3\end{array}$ \\
\hline
\end{tabular}

*Brands used for normalization

the Springfield, Michigan, test market and provided by A. C. Nielsen. Samples used to estimate the model consist of randomly drawn samples from panel members who made at least two purchases over the entire time period. The descriptive statistics associated with the datasets used in the estimation are reported in Table 1.

\subsection{Empirical Results}

4.2.1 Choice Dynamics. The parameter estimates are reported in Tables 2 through 7 . Model 1 results indicate that the lagged price coefficient $\left(\beta_{L}\right)$ is statistically significant in ketchup, peanut butter, detergent, and tissue. Furthermore, the coefficient for the lagged display variable $\left(\omega_{L}\right)$ is statistically significant in the peanut butter and tuna categories. Thus, Chamberlain's test suggests that we can rule out both state dependence and lagged display and price effects in the sugar category. In the rest of the categories, the Chamberlain's test result suggests that there are intertemporal dependencies in the deterministic part of utilities, and, hence, choice dynamics exist.

The Model 2 results suggest that the coefficient for the last purchase $(\rho)$ is statistically significant in all categories except for sugar. Thus, applying Wooldridge's specification, we can conclude that state dependence exists in five product categories, provided that the significance of the lagged purchase coefficient is not a reflection of any omitted significant lagged dynamic responses to exogenous variables or serial correlation.

Thus, we still need to make sure that we are not getting spurious state dependence in Model 2, and we need to ask the question of whether lagged price and display effects exist after controlling for state dependence. The significant lagged price effects in Model 1 may be capturing state dependence or may be indicative of true dynamic responses to price. However, if there are no lagged price or display effects after controlling for lagged purchase effects, we could conclude that for those categories Chamberlain's test is a valid test for state dependence.

To answer these questions, we need to look at the Model 3 results in conjunction with the Model 1 results. Model 3 results suggest that there are no significant lagged price or display (Price ${ }_{i j, t-1}$ and Display ${ }_{i j, t-1}$ ) effects in the five categories in which Chamberlain's test found choice dynamics. [However, since there may be multicollinearity present in Model 3, we also estimate another model (Model 4) by setting the coefficients for $\sum_{t=0}^{T}$ Price $_{i j t}$ and $\sum_{t=0}^{T}$ Display $_{i j t}=0$, as previously discussed. We again obtain insignificant lagged responses to price and display.]

Thus, we obtain insignificant coefficients for the lagged exogenous variables in Model 3 (as well as in Model 4) and significant coefficients of either or both of the exogenous variables in Model 1 in five out of six categories studied. These combined results suggest that in the five categories in which choice dynamics were found the source of choice dynamics is state dependence and and there are no simple lagged responses to prices and displays in these six categories.

4.2.2 Consumer Unobserved Heterogeneity and Heterogeneity Structures. The results from the models are consistent with respect to the existence of significant taste heterogeneity $\left(\sigma_{\alpha}^{2}\right)$ and price-sensitivity heterogeneity $\left(\sigma_{\beta}^{2}\right)$ in all six categories studied. Display-sensitivity heterogeneity exists in all the product categories except for peanut butter and tuna.

Furthermore, the results associated with all three models with the lagged-dependent-variable (Models 2-4) indicate also that there is heterogeneity in state dependence in four out of five categories in which state dependence was found. Tuna is the only category in which the state-dependence coefficient does not show any significant heterogeneity.

Finally, Models 2-4 are illuminating with respect to the appropriateness of a random-effects specification in which the individual effects are independent of the covariates and the initial purchase. The $\sum_{t=0}^{T}$ Price $_{i j t}$ and $\sum_{t=0}^{T}$ Display $_{i j t}$ variables capture all the past prices and displays a household was exposed to for a given brand. Their effect on choice ( $\eta$ and $\pi$, respectively) were found to be insignificant in all categories. This shows that our assumption of the Chamberlain test that the individual effects are uncorrelated with the covariates cannot be rejected empirically. Moreover, the initial purchase dummy $\left(y_{i j 0}\right)$ is found to be statistically insignificant in all categories as well.

\section{CONCLUSION}

For the first time in the marketing literature, Chamberlain's method and Wooldridge's approach to test for state dependence were applied both separately and together in a specification that embeds them both. Using marketing data to test whether there is any state dependence in choice behavior in frequently purchased product categories, we found evidence 
Table 2. Ketchup

\begin{tabular}{|c|c|c|c|c|c|}
\hline Parameters & & Model 1 & Model 2 & Model 3 & Model 4 \\
\hline $\begin{array}{l}\text { Mean brand-specific coefficient } \alpha_{1} \\
\text { Standard deviation of brand coefficient } \sigma_{\alpha 1}\end{array}$ & (Heinz) & $\begin{array}{l}2.26\left(.26^{* *}\right) \\
1.12(.30)\end{array}$ & $\begin{array}{l}2.47(.25) \\
1.32(.29)\end{array}$ & $\begin{array}{l}2.48(.28) \\
1.30(.29)\end{array}$ & $\begin{array}{l}2.56(.31) \\
1.32(.29)\end{array}$ \\
\hline $\begin{array}{l}\text { Mean brand-specific coefficient } \alpha_{2} \\
\text { Standard deviation of brand coefficient } \sigma_{\alpha 2}\end{array}$ & (Hunt) & $\begin{array}{l}.76(.20) \\
.56(.28)\end{array}$ & $\begin{array}{r}1.29(.19) \\
.60(.25)\end{array}$ & $\begin{array}{r}1.67(.29) \\
.63(.30)\end{array}$ & $\begin{array}{r}1.62(.30) \\
.65(.33)\end{array}$ \\
\hline $\begin{array}{l}\text { Mean price coefficient } \beta \\
\text { Standard deviation of price coefficient } \sigma_{\beta}\end{array}$ & & $\begin{array}{r}-2.37(.60) \\
3.29(.54)\end{array}$ & $\begin{array}{r}-2.91(.52) \\
2.95(.68)\end{array}$ & $\begin{array}{r}-3.11(.51) \\
3.06(.70)\end{array}$ & $\begin{array}{r}-3.11(.50) \\
3.04(.68)\end{array}$ \\
\hline $\begin{array}{l}\text { Mean display coefficient } \omega \\
\text { Standard deviation of display coefficient } \sigma_{\omega}\end{array}$ & & $\begin{array}{l}1.73(.50) \\
1.35(.53)\end{array}$ & $\begin{array}{r}1.87(.55) \\
.97(.41)\end{array}$ & $\begin{array}{r}1.91(.56) \\
.97(.44)\end{array}$ & $\begin{array}{r}1.92(.57) \\
.98(.43)\end{array}$ \\
\hline $\begin{array}{l}\text { Mean lagged price coefficient } \beta_{L} \\
\text { Standard deviation of lagged price coefficient } \sigma_{\beta L}\end{array}$ & & $\begin{aligned}-.88(.40) \\
1.03(.73)\end{aligned}$ & & $\begin{aligned} &-.27(.52) \\
& 1.44(.73)\end{aligned}$ & $\begin{array}{r}-.35(.53) \\
1.47(.74)\end{array}$ \\
\hline $\begin{array}{l}\text { Mean lagged display coefficient } \omega_{L} \\
\text { Standard deviation of lagged display coefficient } \sigma_{\omega L}\end{array}$ & & $\begin{array}{l}.10(.36) \\
.40(.92)\end{array}$ & & $\begin{array}{l}.06(.59) \\
.44(1.33)\end{array}$ & $\begin{array}{l}.07(.62) \\
.45(1.36)\end{array}$ \\
\hline $\begin{array}{l}\text { Mean initial-purchase coefficient } \lambda \\
\text { Standard deviation of initial-purchase coefficient } \sigma_{\lambda}\end{array}$ & & & $\begin{aligned}-.06(.20) \\
.47(.39)\end{aligned}$ & $\begin{array}{r}-.22(.21) \\
.01(.76)\end{array}$ & $\begin{array}{r}-.19(.22) \\
.05(.73)\end{array}$ \\
\hline $\begin{array}{l}\text { Mean average price coefficient } \eta \\
\text { Standard deviation of average price coefficient } \sigma_{\eta}\end{array}$ & & & $\begin{array}{r}-1.43(1.01) \\
2.48(.99)\end{array}$ & $\begin{array}{r}.75(1.49) \\
5.87(1.53)\end{array}$ & \\
\hline $\begin{array}{l}\text { Mean average display coefficient } \pi \\
\text { Standard deviation of average display coefficient } \sigma_{\pi}\end{array}$ & & & $\begin{array}{l}-.82(1.42) \\
3.42(1.82)\end{array}$ & $\begin{array}{r}-1.84(1.63) \\
4.18(1.98)\end{array}$ & \\
\hline $\begin{array}{l}\text { Mean last-purchase coefficient } \rho \\
\text { Standard deviation of last-purchase coefficient } \sigma_{\rho}\end{array}$ & & & $\begin{array}{l}.95(.15) \\
.81(.22)\end{array}$ & $\begin{array}{l}.85(.28) \\
.89(.22)\end{array}$ & $\begin{array}{l}.81(.25) \\
.86(.20)\end{array}$ \\
\hline $\begin{array}{l}\text { Log-likelihood } \\
\text { AIC } \\
\text { BIC }\end{array}$ & & $\begin{array}{l}670.98 \\
682.98 \\
713.17\end{array}$ & $\begin{array}{l}627.11 \\
641.11 \\
683.35\end{array}$ & $\begin{array}{l}583.30 \\
603.30 \\
653.60\end{array}$ & $\begin{array}{l}599.47 \\
615.47 \\
655.71\end{array}$ \\
\hline
\end{tabular}

NOTE: $\quad$ Number of observations $=1,132$; number of households $=166$.

Table 3. Peanut Butter

\begin{tabular}{|c|c|c|c|c|c|}
\hline Parameters & & Model 1 & Model 2 & Model 3 & Model 4 \\
\hline $\begin{array}{l}\text { Mean brand-specific coefficient } \alpha_{1} \\
\text { Standard deviation of brand coefficient } \sigma_{\alpha 1}\end{array}$ & (Skippy) & $\begin{array}{r}1.94(.24) \\
.54(.14)\end{array}$ & $\begin{array}{l}1.99(.13) \\
1.06(.14)\end{array}$ & $\begin{array}{l}2.23(.27) \\
1.23(.12)\end{array}$ & $\begin{array}{l}2.21(.26) \\
1.15(.16)\end{array}$ \\
\hline $\begin{array}{l}\text { Mean brand-specific coefficient } \alpha_{2} \\
\text { Standard deviation of brand coefficient } \sigma_{\alpha 2}\end{array}$ & (JIF) & $\begin{array}{r}.42(.26) \\
1.44(.15)\end{array}$ & $\begin{array}{r}.65(.12) \\
1.45(.17)\end{array}$ & $\begin{array}{r}.72(.29) \\
1.53(.15)\end{array}$ & $\begin{array}{r}.79(.29) \\
1.55(.16)\end{array}$ \\
\hline $\begin{array}{l}\text { Mean brand-specific coefficient } \alpha_{3} \\
\text { Standard deviation of brand coefficient } \sigma_{\alpha 3}\end{array}$ & (CTL) & $\begin{array}{r}.65(.31) \\
2.06(.20)\end{array}$ & $\begin{array}{r}.67(.38) \\
1.68(.19)\end{array}$ & $\begin{array}{r}.72(.33) \\
1.83(.13)\end{array}$ & $\begin{array}{r}.77(.34) \\
1.78(.22)\end{array}$ \\
\hline $\begin{array}{l}\text { Mean price coefficient } \beta \\
\text { Standard deviation of price coefficient } \sigma_{\beta}\end{array}$ & & $\begin{array}{r}-1.70(.20) \\
1.79(.23)\end{array}$ & $\begin{array}{r}-1.78(.22) \\
1.33(.24)\end{array}$ & $\begin{array}{r}-1.70(.25) \\
2.05(.26)\end{array}$ & $\begin{array}{r}-1.75(.26) \\
2.00(.25)\end{array}$ \\
\hline $\begin{array}{l}\text { Mean display coefficient } \omega \\
\text { Standard deviation of display coefficient } \sigma_{\omega}\end{array}$ & & $\begin{array}{l}.78(.26) \\
.37(.60)\end{array}$ & $\begin{array}{l}.83(.23) \\
.40(.56)\end{array}$ & $\begin{array}{l}.95(.28) \\
.41(.69)\end{array}$ & $\begin{array}{l}.96(.31) \\
.43(.70)\end{array}$ \\
\hline $\begin{array}{l}\text { Mean lagged price coefficient } \beta_{L} \\
\text { Standard deviation of lagged price coefficient } \sigma_{\beta L}\end{array}$ & & $\begin{array}{r}.49(.20) \\
1.05(.33)\end{array}$ & & $\begin{array}{r}.24(.27) \\
1.09(.36)\end{array}$ & $\begin{array}{r}.29(.25) \\
1.17(.41)\end{array}$ \\
\hline $\begin{array}{l}\text { Mean lagged display coefficient } \omega_{L} \\
\text { Standard deviation of lagged display coefficient } \sigma_{\omega L}\end{array}$ & & $\begin{array}{r}-.50(.23) \\
.57(.52)\end{array}$ & & $\begin{array}{r}-.02(.27) \\
.24(.61)\end{array}$ & $\begin{array}{r}-.06(.31) \\
.26(.65)\end{array}$ \\
\hline $\begin{array}{l}\text { Mean initial-purchase coefficient } \lambda \\
\text { Standard deviation of initial-purchase coefficient } \sigma_{\lambda}\end{array}$ & & & $\begin{array}{r}-.10(.07) \\
.23(.17)\end{array}$ & $\begin{array}{l}.12(.10) \\
.26(.12)\end{array}$ & $\begin{array}{l}.14(.12) \\
.29(.11)\end{array}$ \\
\hline $\begin{array}{l}\text { Mean average price coefficient } \eta \\
\text { Standard deviation of average price coefficient } \sigma_{\eta}\end{array}$ & & & $\begin{array}{r}-.43(.54) \\
2.32(.35)\end{array}$ & $\begin{array}{r}-.51(.92) \\
4.67(.45)\end{array}$ & \\
\hline $\begin{array}{l}\text { Mean average display coefficient } \pi \\
\text { Standard deviation of average display coefficient } \sigma_{\pi}\end{array}$ & & & $\begin{aligned}-1.20(.88) \\
.60(2.47)\end{aligned}$ & $\begin{array}{r}-1.38(1.58) \\
.80(2.49)\end{array}$ & \\
\hline $\begin{array}{l}\text { Mean last-purchase coefficient } \rho \\
\text { Standard deviation of last-purchase coefficient } \sigma_{\rho}\end{array}$ & & & $\begin{array}{l}.18(.06) \\
.70(.08)\end{array}$ & $\begin{array}{l}.15(.07) \\
.65(.09)\end{array}$ & $\begin{array}{l}.10(.04) \\
.67(.11)\end{array}$ \\
\hline $\begin{array}{l}\text { Log-likelihood } \\
\text { AIC } \\
\text { BIC }\end{array}$ & & $\begin{array}{l}3,109.21 \\
3,123.21 \\
3,165.42\end{array}$ & $\begin{array}{l}3,058.82 \\
3,076.82 \\
3,131.09\end{array}$ & $\begin{array}{l}3,011.04 \\
3,033.04 \\
3,099.37\end{array}$ & $\begin{array}{l}3,028.26 \\
3,046.26 \\
3,100.53\end{array}$ \\
\hline
\end{tabular}

NOTE: $\quad$ Number of observations $=2,979 ;$ number of households $=273$. 
Table 4. Liquid Detergent

\begin{tabular}{|c|c|c|c|c|c|}
\hline Parameters & & Model 1 & Model 2 & Model 3 & Model 4 \\
\hline $\begin{array}{l}\text { Mean brand-specific coefficient } \alpha_{1} \\
\text { Standard deviation of brand coefficient } \sigma_{\alpha 1}\end{array}$ & (Wisk) & $\begin{aligned}-.87(.28) \\
2.24(.35)\end{aligned}$ & $\begin{array}{r}-.34(.19) \\
.70(.34)\end{array}$ & $\begin{array}{r}-.37(.19) \\
.71(.34)\end{array}$ & $\begin{array}{r}-.38(.17) \\
.73(.34)\end{array}$ \\
\hline $\begin{array}{l}\text { Mean brand-specific coefficient } \alpha_{2} \\
\text { Standard deviation of brand coefficient } \sigma_{\alpha 2}\end{array}$ & (Tide) & $\begin{array}{r}.24(.23) \\
1.76(.27)\end{array}$ & $\begin{array}{l}.45(.19) \\
.12(.61)\end{array}$ & $\begin{array}{l}.50(.18) \\
.03(.70)\end{array}$ & $\begin{array}{l}.51(.19) \\
.05(.69)\end{array}$ \\
\hline $\begin{array}{l}\text { Mean brand-specific coefficient } \alpha_{3} \\
\text { Standard deviation of brand coefficient } \sigma_{\alpha 3}\end{array}$ & (Surf) & $\begin{array}{l}-.65(.27) \\
2.03(.26)\end{array}$ & $\begin{array}{r}-.18(.20) \\
.88(.33)\end{array}$ & $\begin{array}{r}-.17(.19) \\
.80(.27)\end{array}$ & $\begin{array}{r}-.17(.22) \\
.81(.26)\end{array}$ \\
\hline $\begin{array}{l}\text { Mean brand-specific coefficient } \alpha_{4} \\
\text { Standard deviation of brand coefficient } \sigma_{\alpha 4}\end{array}$ & (Era) & $\begin{aligned}-.60(.38) \\
2.81(.38)\end{aligned}$ & $\begin{array}{l}.12(.25) \\
.95(.35)\end{array}$ & $\begin{array}{l}.18(.24) \\
.85(.34)\end{array}$ & $\begin{array}{l}.20(.23) \\
.86(.32)\end{array}$ \\
\hline $\begin{array}{l}\text { Mean brand-specific coefficient } \alpha_{5} \\
\text { Standard deviation of brand coefficient } \sigma_{\alpha 5}\end{array}$ & (Solo) & $\begin{array}{r}-2.64(.37) \\
4.35(.61)\end{array}$ & $\begin{array}{r}-.73(.35) \\
1.47(.41)\end{array}$ & $\begin{array}{r}-.77(.37) \\
1.54(.42)\end{array}$ & $\begin{aligned}-.80(.32) \\
1.58(.39)\end{aligned}$ \\
\hline $\begin{array}{l}\text { Mean price coefficient } \beta \\
\text { Standard deviation of price coefficient } \sigma_{\beta}\end{array}$ & & $\begin{array}{r}-.85(.14) \\
.81(.25)\end{array}$ & $\begin{array}{r}-.67(.15) \\
.65(.24)\end{array}$ & $\begin{aligned}-.67(.14) \\
.68(.30)\end{aligned}$ & $\begin{aligned}-.65(.15) \\
.69(.29)\end{aligned}$ \\
\hline $\begin{array}{l}\text { Mean display coefficient } \omega \\
\text { Standard deviation of display coefficient } \sigma_{\omega}\end{array}$ & & $\begin{aligned} .54(.21) \\
1.21(.59)\end{aligned}$ & $\begin{array}{l}.73(.32) \\
.70(.67)\end{array}$ & $\begin{array}{r}.55(.36) \\
1.05(.55)\end{array}$ & $\begin{array}{r}.56(.37) \\
1.01(.46)\end{array}$ \\
\hline $\begin{array}{l}\text { Mean lagged price coefficient } \beta_{L} \\
\text { Standard deviation of lagged price coefficient } \sigma_{\beta L}\end{array}$ & & $\begin{array}{r}-.35(.12) \\
.40(.25)\end{array}$ & & $\begin{array}{r}-.14(.13) \\
.43(.30)\end{array}$ & $\begin{array}{r}-.13(.15) \\
.50(.30)\end{array}$ \\
\hline $\begin{array}{l}\text { Mean lagged display coefficient } \omega_{L} \\
\text { Standard deviation of lagged display coefficient } \sigma_{\omega L}\end{array}$ & & $\begin{array}{l}.13(.31) \\
.01(1.14)\end{array}$ & & $\begin{aligned}-.31(.36) \\
.18(2.36)\end{aligned}$ & $\begin{array}{r}-.33(.41) \\
.19(2.40)\end{array}$ \\
\hline $\begin{array}{l}\text { Mean initial-purchase coefficient } \lambda \\
\text { Standard deviation of initial-purchase coefficient } \sigma_{\lambda}\end{array}$ & & & $\begin{array}{l}.15(.27) \\
.64(.69)\end{array}$ & $\begin{array}{l}.25(.28) \\
.82(.57)\end{array}$ & $\begin{array}{l}.22(.31) \\
.83(.50)\end{array}$ \\
\hline $\begin{array}{l}\text { Mean average price coefficient } \eta \\
\text { Standard deviation of average price coefficient } \sigma_{\eta}\end{array}$ & & & $\begin{array}{r}-.35(.26) \\
.78(.37)\end{array}$ & $\begin{array}{r}-.16(.27) \\
.63(.52)\end{array}$ & \\
\hline $\begin{array}{l}\text { Mean average display coefficient } \pi \\
\text { Standard deviation of average display coefficient } \sigma_{\pi}\end{array}$ & & & $\begin{aligned}-.25 & (.73) \\
2.75 & (.73)\end{aligned}$ & $\begin{array}{c}.08(.77) \\
1.83(1.23)\end{array}$ & \\
\hline $\begin{array}{l}\text { Mean last-purchase coefficient } \rho \\
\text { Standard deviation of last-purchase coefficient } \sigma_{\rho}\end{array}$ & & & $\begin{array}{l}1.67(.19) \\
2.34(.27)\end{array}$ & $\begin{array}{l}1.64(.18) \\
2.18(.27)\end{array}$ & $\begin{array}{l}1.58(.21) \\
2.19(.29)\end{array}$ \\
\hline $\begin{array}{l}\text { Log-likelihood } \\
\text { AIC } \\
\text { BIC }\end{array}$ & & $\begin{array}{l}1,309.50 \\
1,327.50 \\
1,370.73\end{array}$ & $\begin{array}{l}1,246.92 \\
1,268.92 \\
1,321.72\end{array}$ & $\begin{array}{l}1,221.17 \\
1,247.17 \\
1,309.57\end{array}$ & $\begin{array}{l}1,237.34 \\
1,259.34 \\
1,312.14\end{array}$ \\
\hline
\end{tabular}

NOTE: Number of observations $=901$; number of households $=252$.

of nonzero-order choice behavior in five out of six categories studied-ketchup, peanut butter, detergent, tissue, and tuna. We could not reject the null hypothesis of no state dependence in sugar. We also find evidence for the appropriateness of a random-effects specification for unobserved consumer taste heterogeneity. Specifically, we found the individual effects to be uncorrelated with the covariates.

Our analysis also confirms the robustness of Chamberlain's test as a state-dependence test in contexts in which the exogenous variables under analysis do not display significant simple direct lagged effects. Most importantly, this research shows that any test for state dependence or dynamic responses to exogenous variables rests on a number of assumptions:

If Chamberlain's test is used alone as a test for state dependence, then one needs to assume that the lagged values of at least one exogenous variable do not affect the current choices. In the case of brand choice, for example, the assumption of absence of dynamic responses of displays could be a plausible assumption. Note that such an assumption would be an economic assumption or an assumption involving consumer behavior rather than a statistical assumption. One needs also to assume the covariates to be uncorrelated with the individual effects.
On the other hand, if the Wooldridge type of laggeddependent-variable specification is the only test used, then the assumption is that serial correlation and unobserved heterogeneity are correctly specified. Note that such assumptions are statistical assumptions that may be less desirable than plausible economic assumptions. Further, one needs to assume that the lagged-dependent-variable coefficient is not picking up any dynamic responses to exogenous variables omitted from the model.

Most importantly, this research shows the need to use a combination of tests such as the Chamberlain test and the Wooldridge test to circumvent the problems associated with them as stand-alone tests. This enables the researcher to make more reliable statements about state dependence and dynamic responses to exogenous variables.

\section{ACKNOWLEDGMENTS}

We thank Michael P. Keane for his helpful comments. We also thank Jeffrey $M$. Wooldridge for his many insightful comments and suggestions. This research was supported by National Science Foundation grant SBR-9812067.

[Received March 1998. Revised September 2000.] 
Table 5. Tissue

\begin{tabular}{|c|c|c|c|c|c|}
\hline Parameters & & Model 1 & Model 2 & Model 3 & Model 4 \\
\hline $\begin{array}{l}\text { Mean brand-specific coefficient } \alpha_{1} \\
\text { Standard deviation of brand coefficient } \sigma_{\alpha 1}\end{array}$ & (NRTHRM) & $\begin{array}{l}2.94(.15) \\
1.16(.16)\end{array}$ & $\begin{array}{r}2.89(.17) \\
.45(.13)\end{array}$ & $\begin{array}{r}2.49(.17) \\
.65(.16)\end{array}$ & $\begin{array}{r}2.49(.20) \\
.66(.17)\end{array}$ \\
\hline $\begin{array}{l}\text { Mean brand-specific coefficient } \alpha_{2} \\
\text { Standard deviation of brand coefficient } \sigma_{\alpha 2}\end{array}$ & (CHRMN) & $\begin{array}{l}2.51(.16) \\
1.09(.18)\end{array}$ & $\begin{array}{r}2.64(.19) \\
.73(.18)\end{array}$ & $\begin{array}{r}2.24(.18) \\
.56(.21)\end{array}$ & $\begin{array}{r}2.25(.19) \\
.59(.22)\end{array}$ \\
\hline $\begin{array}{l}\text { Mean brand-specific coefficient } \alpha_{3} \\
\text { Standard deviation of brand coefficient } \sigma_{\alpha 3}\end{array}$ & (CTNL) & $\begin{array}{l}1.24(.18) \\
1.83(.27)\end{array}$ & $\begin{array}{r}1.84(.24) \\
.69(.31)\end{array}$ & $\begin{array}{l}1.26(.23) \\
1.05(.17)\end{array}$ & $\begin{array}{l}1.28(.24) \\
1.05(.19)\end{array}$ \\
\hline $\begin{array}{l}\text { Mean brand-specific coefficient } \alpha_{4} \\
\text { Standard deviation of brand coefficient } \sigma_{\alpha 4}\end{array}$ & (SCOTT) & $\begin{aligned}-.15(.16) \\
1.15(.19)\end{aligned}$ & $\begin{array}{l}.16(.10) \\
.89(.14)\end{array}$ & $\begin{aligned}-.02(.19) \\
.78(.26)\end{aligned}$ & $\begin{array}{l}.03(.22) \\
.76(.27)\end{array}$ \\
\hline $\begin{array}{l}\text { Mean price coefficient } \beta \\
\text { Standard deviation of price coefficient } \sigma_{\beta}\end{array}$ & & $\begin{array}{r}-10.07(.21) \\
4.89(.76)\end{array}$ & $\begin{aligned}-9.88(.17) \\
5.92(.77)\end{aligned}$ & $\begin{array}{r}-10.72(.78) \\
4.62(.77)\end{array}$ & $\begin{array}{r}-10.68(.70) \\
4.25(.81)\end{array}$ \\
\hline $\begin{array}{l}\text { Mean display coefficient } \omega \\
\text { Standard deviation of display coefficient } \sigma_{\omega}\end{array}$ & & $\begin{aligned} & 1.75(.26) \\
.99 & (.32)\end{aligned}$ & $\begin{array}{r}1.94(.29) \\
.49(.22)\end{array}$ & $\begin{aligned} 1.98(.29) \\
.52(.20)\end{aligned}$ & $\begin{array}{r}1.99(.30) \\
.54(.21)\end{array}$ \\
\hline $\begin{array}{l}\text { Mean lagged price coefficient } \beta_{L} \\
\text { Standard deviation of lagged price coefficient } \sigma_{\beta L}\end{array}$ & & $\begin{array}{l}1.07(.52) \\
1.50(.87)\end{array}$ & & $\begin{array}{l}.75(1.76) \\
.04(.12)\end{array}$ & $\begin{array}{l}.81(1.87) \\
.05(.18)\end{array}$ \\
\hline $\begin{array}{l}\text { Mean lagged display coefficient } \omega_{L} \\
\text { Standard deviation of lagged display coefficient } \sigma_{\omega L}\end{array}$ & & $\begin{array}{l}.46(.35) \\
.57(.33)\end{array}$ & & $\begin{array}{l}.32(.43) \\
.47(.40)\end{array}$ & $\begin{array}{l}.35(.46) \\
.43(.39)\end{array}$ \\
\hline $\begin{array}{l}\text { Mean initial-purchase coefficient } \lambda \\
\text { Standard deviation of initial-purchase coefficient } \sigma_{\lambda}\end{array}$ & & & $\begin{array}{l}.05(.13) \\
.09(.20)\end{array}$ & $\begin{array}{l}.04(.12) \\
.16(.38)\end{array}$ & $\begin{array}{l}.04(.12) \\
.18(.40)\end{array}$ \\
\hline $\begin{array}{l}\text { Mean average price coefficient } \eta \\
\text { Standard deviation of average price coefficient } \sigma_{\eta}\end{array}$ & & & $\begin{array}{l}-.035(.02) \\
.03(.01)\end{array}$ & $\begin{array}{r}-.03(.02) \\
.03(.02)\end{array}$ & \\
\hline $\begin{array}{l}\text { Mean average display coefficient } \pi \\
\text { Standard deviation of average display coefficient } \sigma_{\pi}\end{array}$ & & & $\begin{array}{l}.21(.10) \\
.15(.03)\end{array}$ & $\begin{array}{l}.15(.14) \\
.15(.03)\end{array}$ & \\
\hline $\begin{array}{l}\text { Mean last-purchase coefficient } \rho \\
\text { Standard deviation of last-purchase coefficient } \sigma_{\rho}\end{array}$ & & & $\begin{array}{l}.65(.31) \\
.40(.14)\end{array}$ & $\begin{array}{l}.81(.10) \\
.64(.13)\end{array}$ & $\begin{array}{l}.85(.14) \\
.67(.12)\end{array}$ \\
\hline $\begin{array}{l}\text { Log-likelihood } \\
\text { AIC } \\
\text { BIC }\end{array}$ & & $\begin{array}{l}1,662.03 \\
1,678.03 \\
1,720.11\end{array}$ & $\begin{array}{l}1,638.14 \\
1,658.14 \\
1,710.74\end{array}$ & $\begin{array}{l}1,612.72 \\
1,636.72 \\
1,699.84\end{array}$ & $\begin{array}{l}1,627.91 \\
1,547.91 \\
1,700.51\end{array}$ \\
\hline
\end{tabular}

NOTE: Number of observations $=1,422$; number of households $=171$.

Table 6. Tuna

\begin{tabular}{|c|c|c|c|c|c|}
\hline Parameters & & Model 1 & Model 2 & Model 3 & Model 4 \\
\hline $\begin{array}{l}\text { Mean brand-specific coefficient } \alpha_{1} \\
\text { Standard deviation of brand coefficient } \sigma_{\alpha 1}\end{array}$ & (Starkist) & $\begin{array}{r}.52(.13) \\
1.12(.13)\end{array}$ & $\begin{array}{l}.41(.11) \\
.73(.16)\end{array}$ & $\begin{array}{l}.37(.12) \\
.60(.19)\end{array}$ & $\begin{array}{l}.34(.11) \\
.63(.19)\end{array}$ \\
\hline $\begin{array}{l}\text { Mean price coefficient } \beta \\
\text { Standard deviation of price coefficient } \sigma_{\beta}\end{array}$ & & $\begin{array}{r}-16.65(1.54) \\
8.76(1.78)\end{array}$ & $\begin{array}{r}-16.92(1.62) \\
8.48(1.95)\end{array}$ & $\begin{array}{r}-16.76(1.85) \\
9.02(2.26)\end{array}$ & $\begin{array}{r}-16.56(1.82) \\
9.10(2.27)\end{array}$ \\
\hline $\begin{array}{l}\text { Mean display coefficient } \omega \\
\text { Standard deviation of display coefficient } \sigma_{\omega}\end{array}$ & & $\begin{array}{l}2.16(.39) \\
1.51(.52)\end{array}$ & $\begin{array}{l}2.03(.35) \\
1.48(.42)\end{array}$ & $\begin{array}{l}2.17(.29) \\
1.64(.54)\end{array}$ & $\begin{array}{l}2.21(.30) \\
1.67(.56)\end{array}$ \\
\hline $\begin{array}{l}\text { Mean lagged price coefficient } \beta_{L} \\
\text { Standard deviation of lagged price coefficient } \sigma_{\beta L}\end{array}$ & & $\begin{array}{l}.48(.69) \\
.19(4.13)\end{array}$ & & $\begin{array}{l}.84(.85) \\
.62(5.67)\end{array}$ & $\begin{array}{l}.86(.89) \\
.66(5.41)\end{array}$ \\
\hline $\begin{array}{l}\text { Mean lagged-display coefficient } \omega_{L} \\
\text { Standard deviation of lagged display coefficient } \sigma_{\omega L}\end{array}$ & & $\begin{array}{l}.47(.20) \\
.20(.52)\end{array}$ & & $\begin{array}{l}.18(.21) \\
.06(1.63)\end{array}$ & $\begin{array}{l}.24(.25) \\
.08(1.68)\end{array}$ \\
\hline $\begin{array}{l}\text { Mean initial-purchase coefficient } \lambda \\
\text { Standard deviation of initial-purchase coefficient } \sigma_{\lambda}\end{array}$ & & & $\begin{array}{l}.05(.10) \\
.15(.42)\end{array}$ & $\begin{array}{l}.017(.11) \\
.23(.45)\end{array}$ & $\begin{array}{l}.019(.15) \\
.24(.42)\end{array}$ \\
\hline $\begin{array}{l}\text { Mean average price coefficient } \eta \\
\text { Standard deviation of average price coefficient } \sigma_{\eta}\end{array}$ & & & $\begin{aligned} .57(2.93) \\
2.73(.74)\end{aligned}$ & $\begin{array}{r}-1.24(3.13) \\
5.34(8.34)\end{array}$ & \\
\hline $\begin{array}{l}\text { Mean average display coefficient } \pi \\
\text { Standard deviation of average display coefficient } \sigma_{\pi}\end{array}$ & & & $\begin{aligned}-.30(.77) \\
.02(5.30)\end{aligned}$ & $\begin{array}{r}-.69(.82) \\
.02(4.28)\end{array}$ & \\
\hline $\begin{array}{l}\text { Mean last-purchase coefficient } \rho \\
\text { Standard deviation of last-purchase coefficient } \sigma_{\rho}\end{array}$ & & & $\begin{array}{l}.51(.09) \\
.21(.20)\end{array}$ & $\begin{array}{l}.70(.11) \\
.30(.20)\end{array}$ & $\begin{array}{l}.79(.13) \\
.32(.22)\end{array}$ \\
\hline $\begin{array}{l}\text { Log-likelihood } \\
\text { AIC } \\
\text { BIC }\end{array}$ & & $\begin{array}{l}846.71 \\
856.71 \\
884.37\end{array}$ & $\begin{array}{l}828.55 \\
842.55 \\
881.26\end{array}$ & $\begin{array}{l}804.80 \\
722.80 \\
872.57\end{array}$ & $\begin{array}{l}818.82 \\
832.82 \\
871.53\end{array}$ \\
\hline
\end{tabular}

NOTE: Number of observations $=1,868$; number of households $=151$. 
Table 7. Sugar

\begin{tabular}{|c|c|c|c|c|c|}
\hline Parameters & & Model 1 & Model 2 & Model 3 & Model 4 \\
\hline $\begin{array}{l}\text { Mean brand-specific coefficient } \alpha_{1} \\
\text { Standard deviation of brand coefficient } \sigma_{\alpha 1}\end{array}$ & (CTL) & $\begin{array}{l}3.47(.22) \\
3.00(.17)\end{array}$ & $\begin{array}{l}3.72(.31) \\
2.89(.18)\end{array}$ & $\begin{array}{l}3.81(.33) \\
2.92(.16)\end{array}$ & $\begin{array}{l}3.84(.30) \\
2.95(.17)\end{array}$ \\
\hline $\begin{array}{l}\text { Mean brand-specific coefficient } \alpha_{2} \\
\text { Standard deviation of brand coefficient } \sigma_{\alpha 2}\end{array}$ & (EQUAL) & $\begin{array}{l}2.18(.36) \\
1.86(.20)\end{array}$ & $\begin{array}{l}2.54(.30) \\
1.75(.18)\end{array}$ & $\begin{array}{l}2.62(.32) \\
1.77(.19)\end{array}$ & $\begin{array}{l}2.60(.30) \\
1.74(.17)\end{array}$ \\
\hline $\begin{array}{l}\text { Mean brand-specific coefficient } \alpha_{3} \\
\text { Standard deviation of brand coefficient } \sigma_{\alpha 3}\end{array}$ & (American) & $\begin{array}{l}.27(.04) \\
.53(.06)\end{array}$ & $\begin{array}{l}.32(.04) \\
.54(.05)\end{array}$ & $\begin{array}{l}.33(.05) \\
.56(.06)\end{array}$ & $\begin{array}{l}.33(.05) \\
.55(.06)\end{array}$ \\
\hline $\begin{array}{l}\text { Mean price coefficient } \beta \\
\text { Standard deviation of price coefficient } \sigma_{\beta}\end{array}$ & & $\begin{aligned}-2.25(.14) \\
2.58(.39)\end{aligned}$ & $\begin{array}{r}-2.46(.13) \\
2.54(.36)\end{array}$ & $\begin{array}{r}-2.23(.12) \\
2.60(.40)\end{array}$ & $\begin{array}{r}-2.30(.14) \\
2.59(.37)\end{array}$ \\
\hline $\begin{array}{l}\text { Mean display coefficient } \omega \\
\text { Standard deviation of display coefficient } \sigma_{\omega}\end{array}$ & & $\begin{array}{l}1.49(.29) \\
1.72(.24)\end{array}$ & $\begin{array}{l}1.58(.32) \\
1.78(.27)\end{array}$ & $\begin{array}{l}1.66(.30) \\
1.77(.27)\end{array}$ & $\begin{array}{l}1.65(.31) \\
1.77(.26)\end{array}$ \\
\hline $\begin{array}{l}\text { Mean lagged price coefficient } \beta_{L} \\
\text { Standard deviation of lagged price coefficient } \sigma_{\beta L}\end{array}$ & & $\begin{array}{r}-.34(.34) \\
.59(.56)\end{array}$ & & $\begin{array}{r}-.20(.43) \\
.43(.66)\end{array}$ & $\begin{array}{r}-.22(.46) \\
.44(.69)\end{array}$ \\
\hline $\begin{array}{l}\text { Mean lagged display coefficient } \omega_{L} \\
\text { Standard deviation of lagged display coefficient } \sigma_{\omega L}\end{array}$ & & $\begin{array}{l}.34(.53) \\
.59(.88)\end{array}$ & & $\begin{array}{l}.25(.72) \\
.75(.99)\end{array}$ & $\begin{array}{l}.26(.77) \\
.79(1.02)\end{array}$ \\
\hline $\begin{array}{l}\text { Mean initial-purchase coefficient } \lambda \\
\text { Standard deviation of initial-purchase coefficient } \sigma_{\lambda}\end{array}$ & & & $\begin{array}{l}.39(.67) \\
.26(.35)\end{array}$ & $\begin{array}{l}.36(.59) \\
.33(.40)\end{array}$ & $\begin{array}{l}.38(.60) \\
.34(.39)\end{array}$ \\
\hline $\begin{array}{l}\text { Mean average price coefficient } \eta \\
\text { Standard deviation of average price coefficient } \sigma_{\eta}\end{array}$ & & & $\begin{array}{r}-.26(.22) \\
.14(.20)\end{array}$ & $\begin{array}{r}-.19(.32) \\
.14(.21)\end{array}$ & \\
\hline $\begin{array}{l}\text { Mean average display coefficient } \pi \\
\text { Standard deviation of average display coefficient } \sigma_{\pi}\end{array}$ & & & $\begin{array}{l}.56(.43) \\
.41(.30)\end{array}$ & $\begin{array}{r}-.32(.54) \\
.33(.46)\end{array}$ & \\
\hline $\begin{array}{l}\text { Mean last-purchase coefficient } \rho \\
\text { Standard deviation of last-purchase coefficient } \sigma_{\rho}\end{array}$ & & & $\begin{array}{l}.59(.48) \\
.82(.73)\end{array}$ & $\begin{array}{l}.45(.56) \\
.78(.47)\end{array}$ & $\begin{array}{l}.49(.58) \\
.79(.50)\end{array}$ \\
\hline $\begin{array}{l}\text { Log-likelihood } \\
\text { AIC } \\
\text { BIC }\end{array}$ & & $\begin{array}{l}943.76 \\
957.76 \\
993.57\end{array}$ & $\begin{array}{l}928.17 \\
946.12 \\
992.22\end{array}$ & $\begin{array}{l}916.84 \\
838.84 \\
985.16\end{array}$ & $\begin{array}{l}923.05 \\
941.05 \\
987.13\end{array}$ \\
\hline
\end{tabular}

NOTE: Number of observations $=1,232$; number of households $=134$.

\section{REFERENCES}

Ailawadi, K. L., Gedenk, K., and Neslin, S. A. (1999), "Heterogeneity and Purchase Event Feedback in Choice Models: An Empirical Analysis With Implications for Model Building," International Journal of Research in Marketing, 16, 177-198.

$\rightarrow$ Bass, F. M., Givon, M. M., Kalwani, M. U., Reibstein, D., and Wright, G. P. (1984), "An Investigation into the Order of the Brand Choice Process," Marketing Science, 3, 267-287.

Bass, F. M., and Wind, J. (1995), "Introduction to the Special Issue: Empirical Generalizations in Marketing," Marketing Science, 14, G1-5.

Chamberlain, G. (1978), "On the Use of Panel Data," paper presented at the Social Science Research Council Conference on life-cycle aspects of employment and the labor market, Mt. Kisco, NY.

Erdem, T. (1996), "A Dynamic Analysis of Market Structure Based on Panel Data," Marketing Science, 15, 359-378.

$\rightarrow$ Givon, M. (1984), "Variety Seeking Through Brand Switching," Marketino Science, 3, 1-22.

Gönül, F., and Srinivasan, K. (1993), "Modeling Multiple Sources of Heterogeneity in Multinomial Logit Models: Methodological and Empirical Issues," Marketing Science, 12, 213-229.

Guadagni, P. M., and Little, J. D. C. (1983), "A Logit Model of Brand Choice Calibrated on Scanner Data," Marketing Science, 203-238.

Gupta, S. (1988), "Impact of Sales Promotions on When, What and Hov Much to Buy," Journal of Marketing Research, 25, 1-15.

Heckman, J. (1981), "Heterogeneity and State Dependence," in Studies $i_{-} \rightarrow$ Labor Markets, ed. S. Rosen, Chicago: University of Chicago Press, pp. 91-139.

Hsiao, C. (1986), Analysis of Panel Data, New York: Econometric Societ; $\rightarrow$ Monographs.

$\rightarrow$ Kahn, B., Kalwani, M. U., and Morrison, D. G. (1986), "Measuring Variety Seeking and Reinforcement Behaviors Using Panel Data," Journal of Marketing Research, 23, 89-100.
Keane, M. P. (1993), "Simulation Estimation for Panel Data Models With Limited Dependent Variables," in Handbook of Statistics, eds. G. S. Maddala, C. R. Rao, and H. D. Vinod, New York: Elsevier, pp. 545-571.

(1994), "A Computationally Practical Simulation Estimator for Panel Data," Econometrica, 62, 95-116.

- (1997), "Modeling Heterogeneity and State Dependence in Consumer Choice Behavior," Journal of Business \& Economic Statistics, 15, 310-327

McFadden, D. (1974), "Conditional Logit Analysis of Qualitative Choice Behavior," Frontiers in Econometrics, ed. P. Zarembka, New York: Academic Press, pp. 105-142.

- (1989), "A Method of Simulated Moments for Estimation of Discrete Response Models Without Numerical Integration," Econometrica, 57, 1027-1058

Pakes, A. (1987), "Patents as Options: Some Estimates of the Value of Holding European Patent Stocks," Econometrica, 54, 755-784.

Pedrick, J. H., and Zufryden, F. S. (1991), "Evaluating the Impact of Advertising Media Plans: A Model of Consumer Purchase Dynamics Using SingleSource Data," Marketing Science, 10, 111-130.

Roy, R., Chintagunta, P. K., and Haldar, S. (1996), "A Framework for Investigating Habits, 'The Hand of the Past,' and Heterogeneity in Dynamic Brand Choice," Marketing Science, 15, 280-299.

Tellis, G. (1988), "Advertising Exposure, Loyalty and Brand Purchase," Journal of Marketing Research, 25, 134-144.

Uncles, M., Ehrenberg, A., and Hammond, K. (1995), "Patterns of Buyer Behavior: Regularities, Models, and Extensions," Marketing Science, 14, G71-78.

Winer, R. S. (1986), "A Reference Price Model of Brand Choice for Frequently Purchased Products," Journal of Consumer Research, 13, 250-256.

Wooldridge, J. M. (1998), "Econometric Analysis of Cross Section and Panel Data," mimeo, Michigan State University, Economics Dept. 